\title{
TERPAAN BERITA LINGKUNGAN DAN RASA INGIN TAHU TENTANG ISU LINGKUNGAN SERTA PERILAKU PENOLAKAN PRODUK TIDAK RAMAH LINGKUNGAN
}

\author{
M Sunu Probo Baskoro ${ }^{1^{*}}$, Muhammad Zid ${ }^{2^{*}}$, Samadi $^{3^{*}}$ \\ ${ }^{1}$ Manajemen Lingkungan, Program Pasca Sarjana Universitas Negeri Jakarta, Gedung Bung Hatta Lt 2 Program \\ Pasca Sarjana Universitas Negeri Jakarta, 13220 Rawamangun Jakarta \\ ${ }^{2}$ Pendidikan Geografi, Fakultas Pendidikan Ilmu Pengetahuan Sosial, Universitas Pendidikan Indonesia, Gedung \\ Nu'man Soemantri Jl Dr Setiabudhi No 229 Bandung 40154 Jawa Barat indonesia \\ ${ }^{3}$ Pendidikan Geografi, Fakultas Ilmu Sosial Universitas Negeri Jakarta, Gedung K Kampus Universitas Negeri \\ Jakarta, Jl Rawamangun Muka Jakarta Timur, 13220, Jakarta, Indonesia
}

\begin{abstract}
Abstrak
Tujuan penelitian ini untuk mengetahui adakah hubungan antara Terpaan Berita Lingkungan dengan Perilaku Penolakan Produk tidak Ramah Lingkungan, juga mengetahui adakah hubungan antara Rasa Ingin Tahu atas Isu Lingkungan dengan Perilaku Penolakan Produk tidak Ramah Lingkungan serta mengetahui hubungan kedua variable bebas yakni Terpaan Berita Lingkungan dan Rasa Ingin Tahu atas Isu Lingkungan dengan Perilaku Penolakan Produk tidak Ramah Lingkungan. Penelitian dilakukan pada karyawan Lembaga Kantor Berita Nasional Antara Divisi Pemberitaan TV pada Desember 2018 hingga Januari 2019. Menggunakan sample sebanyak 60 orang dan pengumpulan data menggunakan teknik kuesioner dan observasi lapangan. Hasil penelitian didapati bahwa terdapat hubungan positif antara Terpaan Berita Lingkungan dengan Perilaku Penolakan Produk tidak Ramah Lingkungan, selain itu didapati pula hubungan positif antara Rasa Ingin Tahu atas Isu Lingkungan dengan Perilaku Penolakan Produk tidak Ramah Lingkungan. Kedua variable bebas itu juga mempunyai hubungan positif denga Perilaku Penolakan Produk tidak Ramah Lingkungan.
\end{abstract}

Kata kunci: terpaan berita lingkungan, rasa ingin tahu atas isu lingkungan, perilaku penolakan produk tidak ramah lingkungan, produk tidak ramah lingkungan, lingkungan.

\begin{abstract}
The purpose of this research is to find out whether there is a relationship between environmental news exposure and rejection behavior of non-environmentally friendly products, also to find out is there a relationship between curiosity over environmental issues and rejection behavior of unfriendly products and to know the relationship between the two independent variables namely exposure to environmental news and sense of wanted know the environmental issues with non-environmentally friendly product rejection behavior. the study was conducted on employees of the national news agency agency between the tv news division in december 2018 to january 2019. using a sample of 60 people and data collection using questionnaires and field observations. the results of the study found that there was a positive relationship between the exposure of environmental news to the rejection behavior of non-environmentally friendly products, in addition there was also found a positive relationship between curiosity over environmental issues and the rejection behavior of non-environmentally friendly products. both independent variables also have a positive relationship with the rejection behavior of products that are not environmentally friendly.
\end{abstract}

Keywords: environmental news exposure, curiosity over environmental issues, rejection behavior of unfriendly product, unfriendly product, environmental. 


\section{PENDAHULUAN}

Sepanjang tahun 2016 Lembaga Swadaya Masyarakat Wahana Lingkungan Hidup atau biasa disebut sebagai Walhi, menyatakan telah menerima sebanyak dua puluh lima laporan ataupun pengaduan kasus-kasus tentang lingkungan hidup dari masyarakat. Dari dua puluh lima kasus itu, tiga kasus merupakan pencemaran limbah industri di Kabupaten Bandung, selain laporan pencemaran limbah Industri, Wahana Lingkungan Hidup juga mendapat pengaduan terkait kerusakan daerah aliran sungai. (Bilal Ramadhan, 2016).

Permasalahan lingkungan sebagai akibat dari aktivitas manusia, baik secara langsung maupun tidak langsung telah menjadi isu internasional. Berbagai belahan dunia tengah berupaya untuk mengurangi aktivitas-aktivitas yang dapat memperparah kerusakan-kerusakan pada lingkungan. Pandangan dan pola hidup manusia pun mulai bergeser seiring dengan meningkatnya kepedulian dan kesadaran terhadap lingkungan. Hal ini dibuktikan dengan adanya tuntutan bagi para pelaku bisnis untuk melakukan tanggung jawab lingkungan.

Jaminan ramah lingkungan atau lazim disebut dengan eco-label, menunjukkan bahwa produk itu terjamin mutunya. Negaranegara seperti Cina, Jepang, Korea, India, Thailand, Malaysia, dan Singapura telah tanggap dalam mengatasi isu-isu lingkungan.
Pemerintah di Negara-negara itu mendukung aksi pelestarian lingkungan. Salah satu bentuk dukungan yang diberikan oleh pemerintah berupa pemberian eco-label untuk green product. Dengan demikian green product menjadi mudah dibedakan dari produk-produk tradisional yang dijual dipasaran. (Erlinda Muslim and Dyah Rusty Indriani, 2014)

Begitu juga yang terjadi dengan masyarakat perkotaan. Masyarakat urban mempunyai pola hidup serba instan dan cepat menuntut gaya hidup yang ringkas dan tidak berbelit-belit. Mereka cenderung membeli air mineral kemasan dibandingkan dengan membawa botol minuman untuk diisi ulang. Ketika membeli makanan pun perilaku yang dilakukan oleh masyarakat urban juga sama, mereka lebih memilih membeli makanan yang mempunyai kemasan terutama makanan cepat saji, sehingga setelah selesai menyantap makanan itu, mereka akan membuang kemasan tersebut.

Jakarta sebagai kota metropolitan, sepanjang tahun 2017 menghasilkan 2,2 juta ton. Dalam sehari, 6.000 ton sampah dihasilkan oleh Jakarta, mayoritas sampah itu merupakan sampah organik sebesar 53.75 persen, sampah plastik 14,02 persen, sampah campuran sebesar 11,94 persen, sampah kaca 2,45 persen, sampah logam sebesar 1,82 persen dan sampah tekstil sebesar 1,11 persen.

Menurut asalnya, sampah Jakarta 
dihasilkan dari permukiman mencapai 60,5 persen, sampah perkantoran 22,5 persen, sampah industry, hotel dan toko sebesar 3,4 persen, sampah sekolah sebesar 0,2 persen, sampah pasar sebesar 2,8 persen dan sampah terminal, jalan, dan taman sebesar 10,6 persen. (Fitriyani, 2018)

Sampah yang berasal dari perkantoran menduduki peringkat kedua penghasil sampah di Jakarta. Hal ini menjadi permasalahan tersendiri bagi Pemerintah Provinsi DKI Jakarta untuk mengurangi produksi sampah di Jakarta. Sosialisasi perlunya tindakan Reuse, Reduce, dan Recycle melalui berbagai media massa perlu dilakukan guna merubah perilaku masyarakat dalam pengelolaan sampah.

Media merupakan alat atau sarana yang digunakan untuk menyampaikan pesan dari komunikator kepada khalayak dengan menggunakan alat-alat komunikasi mekanis seperti surat kabar, film, radio dan televisi, Beberapa pendekatan, ada yang memandang media sebagai pembentuk (constructors atau shaper), yakni keyakinan bahwa isi yang disebarkan oleh media memiliki kekuatan untuk mempengaruhi masa depan masyarakat, inilah yang disebut sebagai media sebagai pembentuk. Istilah Komunikasi (communications) berasal dari kata: common yang berarti "sama", dengan maksud sama makna, sehingga secara sederhana dapat dikatakan bahwa komunikasi merupakan proses menyamakan persepsi, pikiran dan rasa antara komunikator dengan komunikan. (Mondry, 2008).

Menurut Denis McQuail, media massa memiliki sifat atau karakteristik yang mampu menjangkau massa dalam jumlah besar dan luas (universality of reach), bersifat public dan mampu memberikan popularitas kepada siapa saja yang muncul di media massa. Karakteristik media itu, memberikan konsekuensi bagi kehidupan politik dan budaya masyarakat kontemporer dewasa ini. Dari perspektif politik, media massa telah menjadi elemen penting dalam proses demokratisasi, karena menyediakan arena dan saluran bagi debat public, menjadikan calon pemimpin politik dikenal luas masyarakat, dan juga berperan menyebarluaskan berbagai informasi dan pendapat. (Morrisan, 2010)

Masyarakat perkotaan dianggap masyarakat yang melek media, mereka dapat mendapatkan informasi dari manapun dan dimanapun. Berita-berita yang berkaitan dengan lingkungan dapat mereka dapatkan melalui surat kabar, media online, radio dan televisi. Hal ini membuat masyarakat perkotaan lebih paham dan mengerti tentang isu-isu lingkungan terutama di kota-kota besar.

Proses pendalaman suatu informasi dimulai dengan adanya keinginan rasa ingin tahu yang lebih dari dalam diri seseorang. Kondisi itu biasa dikalangan masyarakat disebut sebagai “kepo”. Untuk mengatasi 
rasa kepo itu, selanjutnya mereka akan melanjutkan pencariannya dengan mengakses berbagai sumber-sumber informasi untuk memenuhi.

Untuk memenuhi rasa keingin tahuannya masyarakat dapat memilih berbagai media massa yang ada, salah satunya adalah media online atau aplikasi berita-berita online. Ada banyak penyedia berita-berita online yang dapat diunduh dalam ponsel. Beberapa penyedia beritaberita online adalah, Kompas.com, Kumparan.com, Republika.co.id, dan Detik.com. Para penyedia berita-berita online inipun dalam menyediakan pemberitaannya selalu menerbitkan berita-berita lingkungan, baik terkait berita-berita kerusakan lingkungan, mitigasi bencana, sertifikasi produk ramah lingkungan dan kebijakankebijakan lingkungan. Dengan kata lain, perilaku pencarian informasi adalah suatu kegiatan atau aktivitas dari individu dalam mencari informasi yang dibutuhkan atau diinginkan dengan suatu tujuan tertentu. (Ashri Noorida Permana, 2016)

TD Wilson menyebutkan bahwa sebuah model perilaku informasi, dalam model ini dinyatakan bahwa perilaku pencarian informasi merupakan hasil dari adanya kesadaran atas beberapa kebutuhan yang dirasakan oleh pengguna. Terdapat pendekatan pencarian informasi berdasarkan aspek perasaan (afektif), pemikiran (kognitif), dan tindakan fisik (konasi) yang dilihat dari perspektif seseorang dalam melakukan pencarian informasi. (Ashri Noorida Permana, 2016)

Dengan lebih detil Undang-undang No 40 Tahun 1999 tentang Pers pada pasal 6 menegaskan bahwa Pers nasional melaksanakan peranannya untuk memenuhi hak masyarakat untuk mengetahui apa yang diperlukan. Pada pasal sebelumnya yakni pada pasal 3 Undang-undang No 40 Tahun 1999 tentang Pers juga dijelaskan bahwa fungsi dari Pers nasional adalah sebagai media informasi, pendidikan, hiburan dan control social.

Masyarakat dalam menerima terpaan berita-berita lingkungan pada media online juga melalui beberapa tahapan, tahapantahapan itu adalah tahapan ketidakpastian, setelah itu menuju tahapan kesepahaman. Namun sebelum mencapai tahapan kesepahaman ada beberapa tahapan sebelumnya yakni, 6 tahapan dalam pencarian informasi, yaitu dari awalan (initiation), pemilihan (selection), penjelajahan (exploration), penyusunan (formulation), pengumpulan (collection), dan penyajian (presentation).

Perilaku penolakan merupakan perilaku yang sangat tidak produktif dalam suatu organisasi. Jason A Colquitt menyebutkan bahwa perilaku tidak produktif atau yang disebut sebagai Counterproductive behavior adalah sebagai perilaku karyawan 
yang secara sengaja menghambat pencapaian tujuan organisasi.

Colquitt menekankan pada kata "secara sengaja", adalah aspek kunci dari definisi ini, perilaku itu merupakan kegiatan yang disengaja untuk menghambat tujuantujuan dari organisasi dan bukanlah merupakan kejadian yang terjadi dengan tidak sengaja. Ada banyak hal yang dapat dilakukan oleh anggota organisasi untuk menghambat pencapaian sebuah organisasi. Beberapa hal itu adalah pengrusakan terhadap aset-aset milik perusahaan. Selain itu Counter productive behaviour juga didefinisikan sebagai segala kehendak ataupun perilaku yang dilakukan oleh karyawan yang berpotensi melanggar kepentingan, atau membahayakan organisasi dan pemangku kepentingan lainnya. (Jason A. Colquitt, 2013)

Ketika anggota organisasi melakukan pengrusakan terhadap aset-aset organisasi, mereka biasanya melakukan sabotase, sabotase diartikan sebagai penghancuran secara sengaja peralatan fisik, proses organisasi atau produk perusahaan. Hal lain yang dilakukan adalah pencurian, ketika seorang anggota organisasi melakukan pengrusakan aset-aset perusahaan maka pencurian dapat dikategorikan sebuah sabotase yang berbiaya mahal. ${ }^{1}$ Sabotase yang dilakukan oleh karyawan juga didefinisikan sebagai tindakan, yang menyebabkan kerugian bagi organisasi dengan melakukan pengrusakan peralatanperalatan organisasi, melukai rekan kerja, pelanggan ataupun reputasi organisasi.

Skinner menyatakan bahwa perilaku dapat dibedakan menjadi dua, pertama, yakni perilaku yang alami innate behaviour yaitu, perilaku yang dibawa sejak organisme dilahirkan yang berupa refleksrefleks dan insting-insting. Kedua, perilaku operan atau operant behaviour yakni perilaku yang dibentuk melalui proses belajar. (Febriya Viva, Inggrid Weddy 2016)

Hal lain yang merupakan perilakuperilaku counterproductive adalah penyimpangan produksi. Penyimpangan produksi atau Production deviance dapat diartikan sebagai kegiatan yang diarahkan terhadap organisasi namun terfokus secara khusus pada pengurangan efisiensi keluaran kerja atau hasil kerja. Selain itu anggota organisasi juga biasanya melakukan, membuang-buang sumber daya atau Wasting resources dapat diartikan sebagai Pemborosan sumber daya adalah bentuk penyimpangan produksi yang paling umum saat karyawan menggunakan banyak bahan atau terlalu banyak waktu untuk melakukan terlalu sedikit pekerjaan

Sementara itu menurut Roozen dan De Pelsmacker, atribut merek hijau (Green 
Brand Attribute), didefinisikan sebagai atribut spesifik merek dan relasi manfaatnya dalam mengurangi dampak terhadap lingkungan. (Anthony C. Klotz, M. Ronald Buckley, 2013)

Model Uses and Gratification Theory, atau biasa disebut teori penggunaan dan kepuasan sering dinilai sebagai gagasan yang memandang media memberikan efek terbatas kepada audiensi. Dengan kata lain, teori ini menjamin kemampuan individu untuk melakukan control terhadap media yang mereka konsumsi karena media memiliki kemampuan terbatas untuk mempengaruhi audiensi. Pada 1975, Melvin De Fleur dan Sandra Ball-Rokeach mengemukakan gagasan mereka mengenai teori ketergantungan (dependency theory) yang membahas mengenai kekuatan media massa dalam mempengaruhi khalayak audiensi karena adanya sifat ketergantungan. (Morissan, Andy Corry Wardhani dan Farid Hamid, 2013)

Rakhmat menjelaskan bahwa media exposure atau terpaan media adalah banyaknya informasi yang diperoleh melalui media, yang meliputi frekuensi, atensi dan durasi penggunaan pada setiap jenis media yang digunakan. (Prasdianingrum Ayuningtias, 2013) Terpaan media menurut Shore tidak hanya menyangkut apakah seseorang secara fisik cukup dekat dengan kehadiran media massa, tetapi apakah seseorang itu benar-benar terbuka terhadap pesan-pesan media tersebut. Terpaan media merupakan kegiatan mendengarkan, melihat, dan membaca pesan media massa atapun mempunyai pengalaman dan perhatian terhadap pesan tersebut, yang dapat terjadi pada tingkat individu.

Menurut DeFleur dan Rokeach, derajat ketergantungan terhadap media merupakan kunci dalam memahami kapan dan mengapa pesan media massa dapat mengubah kepercayaan, perasaan dan perilaku audiensi. Masyarakat modern semakin tergantung pada media untuk: (a) memahami dunia social mereka; (b) bertindak secara bermakna dan efektif dalam masyarakat; dan (c) untuk menemukan fantasi dan untuk pelarian. Derajat ketergantungan khalayak terhadap media ditentukan oleh; (a) tingkat kepentingan informasi yang disampaikan media; (b) derajat perubahan dan konflik yang terjadi dalam masyarakat. (Morrissan, 2013)

DeFleur dan Rokeach mengemukakan dua factor yang menentukan ketergantungan seseorang terhadap media:

Pertama, seseorang akan lebih bergantung pada media yang dapat memenuhi sejumlah kebutuhannya sekaligus dibandingkan dengan media yang hanya mampu memenuhi beberapa kebutuhan saja

Kedua, perubahan social dan konflik yang terjadi di masyarakat dapat menyebabkan perubahan pada institusi, kepercayaan, dan kegiatan yang sudah mapan. Situasi social 
yang bergejolak (perang, bencana, dan kerusuhan) dapat menimbulkan perubahan pada konsumsi media. Seseorang akan menjadi lebih bergantung pada media untuk mendapatkan informasi atau berita. Pada situasi social yang stabil kebutuhan media juga akan berubah dimana orang lebih menyukai program hiburan.

Menurut model yang disebut dengan uses and dependency model, (model penggunaan dan ketergantungan) ini, beberapa elemen tertentu dalam system media seperti struktur masyarakat, perbedaan individu, dan system media itu sendiri menyebabkan orang menggunakan dan bergantung pada media. Ketergantungan pada media akan menimbulkan efek pada media itu sendiri. Semakin besar ketergantungan seseorang terhadap media, maka semakin besar pula efek yang dapat ditimbulkan media terhadap orang bersangkutan.

Menurut Muhibbin, proses belajar didefinisikan sebagai perubahan perilaku afektif, kognitif, psikomotor yang bersifat positif dalam arti berorientasi kearah yang lebih maju dari pada keadaan sebelumnya. (Irna Hanifah Ameliah, Mumun Munawaroh, Arif Muchyidin, 2016) Sulistyowati, berpendapat ingin tahu adalah sikap dan tindakan yang selalu berupaya untuk mengetahui lebih mendalam dan meluas dari apa yang dipelajarinya, dilihat dan didengar. Istilah itu juga dapat digunakan untuk menunjukkan perilaku itu sendiri yang disebabkan oleh emosi ingin tahu, karena emosi ini mewakili kehendak untuk mengetahui hal-hal baru, rasa ingin tahu diibaratkan "bensin" atau kendaraan ilmu dan disiplin lain dalam studi yang dilakukan oleh manusia.

Untuk memenuhi rasa keingin tahuannya masyarakat dapat memilih berbagai media massa yang ada, salah satunya adalah media online atau aplikasi berita-berita online. Ada banyak penyedia berita-berita online yang dapat diunduh dalam ponsel. Beberapa penyedia beritaberita online adalah, Kompas.com, Kumparan.com, Republika.co.id, dan Detik.com. Para penyedia berita-berita online inipun dalam menyediakan pemberitaannya selalu menerbitkan berita-berita lingkungan, baik terkait berita-berita kerusakan lingkungan, mitigasi bencana, sertifikasi produk ramah lingkungan dan kebijakankebijakan lingkungan. Dengan kata lain, perilaku pencarian informasi adalah suatu kegiatan atau aktivitas dari individu dalam mencari informasi yang dibutuhkan atau diinginkan dengan suatu tujuan tertentu.

Kementerian Pendidikan Nasional mendefinisikan rasa ingin tahu merupakan cara berpikir, sikap dan perilaku yang mencerminkan penasaran dan keingintahuan terhadap segala hal yang dilihat, didengar dan dipelajari secara mendalam. Rasa ingin tahu merupakan titik awal dari pengetahuan yang 
dimiliki oleh manusia. Sesuai dengan pernyataan Suriasumantri (2007) bahwa pengetahuan dimulai dari rasa ingin tahu. Rasa ingin tahu terjadi karena seseorang menganggap bahwa sesuatu yang dipelajari merupakan hal baru yang harus diketahui untuk menjawab ketidaktahuannya.

Carol C Kuhlthau, menjelaskan model kegiatan pencarian informasi sebagai sebuah proses konstruksi yang dilalui oleh seseorang dari tahap ketidakpastian (uncertainly) menuju pada tahap pemahaman (understanding). Berdasarkan pendekatan itu, Kuhlthau membagi pada 6 tahapan dalam pencarian informasi, yaitu dari awalan (initiation), pemilihan (selection), penjelajahan (exploration), penyusunan (formulation), pengumpulan (collection), dan penyajian (presentation). (Ashri Noorida Permana, Pawit M. Yusup, Nuning Kurniasih, 2016)

Manusia sebagai mahluk yang memiliki akal menjadikannya lebih bernilai dari mahluk lainnya. Akal yang dimiliki manusia memungkinkan untuk selalu dikembangkan dalam kehidupannya karena manusia sejatinya adalah mahluk social yang selalu berinteraksi dengan lingkungan sekitar. Akal inilah yang mendorong rasa ingin tahu terhadap segala hal yang sebelumnya tidak diketahui. Manusia yang memiliki rasa ingin tahu akan terdorong untuk terus mencari tahu segala hal yang memang belum diketahui dan dipahami, baik yang diamati dan dipikirkan. Selalu ada keinginan untuk memahami secara lebih mendalam dan mendetail hingga merasa puas.

Ardiyanto menyatakan bahwa rasa ingin tahu akan membuat seseorang menjadi pemikir aktif, pengamat yang aktif, yang kemudian akan memotivasi seseorang itu untuk mempelajari lebih dalam sehingga akan membawa kepuasan dalam dirinya dan meniadakan rasa bosan untuk terus belajar. Kegiatan mempelajari apa yang menjadikan ingin tahu itu akan mendorong seseorang untuk terus belajar, sehingga setelah mereka mengetahui segala hal yang sebelumnya tidak diketahui akan menimbulkan kepuasan tersendiri dalam dirinya. (Mydha Tri Puspitasari, Sigit Santoso, Binti Muchsini, 2015)

Keingintahuan merupakan suatu emosi yang berkaitan dengan perilaku ingin tahu seperti, eksplorasi, investigasi dan keinginan belajar. Schmitt dan Lahroodi mengeksplorasi nilai rasa ingin tahu untuk penyelidikan dan pengetahuan. Rasa ingin tahu adalah keinginan untuk belajar dan mempelajari sesuatu agar mendapat informasi ataupun pengetahuan baru. Belajar bukan sekedar mengetahui namun mengeksplorasi guna mengetahui lebih lanjut sehingga memberi makna atas apa yang diperoleh dalam proses belajar. 


\section{METODOLOGI}

Penelitian ini merupakan penelitian korelasional. Penelitian ini dilakukan ketika suatu peristiwa yang di dalamnya terdapat variable terikat dan bebas telah terjadi. Pada penelitian ini variable bebasnya adalah terpaan berita lingkungan dan rasa ingin tahu atas isu lingkungan sedangkan variable terikat dari penelitian ini adalah, perilaku penolakan produk tidak ramah lingkungan.

Populasi sasaran pada penelitian ini adalah seluruh karyawan divisi pemberitaan tv di Lembaga Kantor Berita Nasional Antara. Penentuan sample pada penelitian ini menggunakan teknik simple random sampling.

Tahapan pengambilan sample adalah sebagai berikut, (a) Peneliti menentukan sample menggunakan rumus Slovin, dari 115 jumlah seluruh karyawan Divisi Pemberitaan tv Antara didapatkan sample sebanyak 60 orang, (b) Untuk menentukan keenam puluh orang itu peneliti mengundi atau mengocok ke-115 orang itu hingga jumlahnya 60 orang, (c) Kepada ke-60 karyawan Antara itu akan diberikan kuesioner penelitian berisi instrument penelitian, (d) Langkah untuk mendapatkan data dalam penelitian ini dengan menggunakan instrumen sebagai alat ukur. instrumen disusun dengan mengacu pada teori yang digunakan, pengembangan dan penyusunan instrumen ditempuh melalui beberapa langkah (a) Mengkaji teori yang berhubungan dengan variabel- variabel penelitian yaitu terpaan berita lingkungan, rasa ingin tahu isu lingkungan dan perilaku penolakan produk tidak ramah lingkungan; (b) Menyusun indikator berdasarkan dimensi dari setiap variabel dan aspek-aspek yang akan diukur; (c) Menuliskan item-item pernyataan dengan menggunakan rubrik untuk skala pengukurannya. Untuk menguji keabsahan dari item-item instrumen dilakukan uji coba.

Secara garis besar untuk menguji instrumen layak digunakan atau tidak terdapat dua indikator yaitu, kesahihan atau validitas dan keterandalan atau reliabilitas. Untuk memperoleh gambaran yang jelas serta untuk menghindari penafsiran yang berbeda-beda perlu dijelaskan beberapa istilah dan cara pengukuran variabel yang digunakan untuk penelitian ini disesuaikan dengan variabel yang akan diteliti.

Instrumen yang digunakan untuk mengukur perilaku penolakan produk tidak ramah lingkungan adalah soal pernyataan berdasarkan dimensi dari teori Jason A Colquit. Soal terdiri dari 32 pernyataan dengan 5 alternatif jawaban. Jawaban tertinggi diberi nilai 5 sedangkan terendah diberi nilai 1. Instrumen yang digunakan dihitung menggunakan software SPSS ver 22.

Berdasarkan uji validitas terhadap Instrumen Perilaku Penolakan Produk tidak Ramah Lingkungan sebanyak 32 butir pernyataan terdapat 5 soal tidak valid. 
Sehingga butir valid sebanyak 27 pernyataan digunakan untuk menjaring data berikutnya. Peniliti juga melakukan uji validitas terhadap Instrumen Terpaan Berita Lingkungan sebanyak 36 butir pernyataan, terdapat 4 soal tidak valid sehingga butir valid sebanyak 32 pernyataan digunakan untuk menjaring data berikutnya. Terakhir, peneliti mevalidasi Instrumen Rasa Ingin Tahu atas Isu Lingkungan sebanyak 24 pernyataan, terdapat 3 soal tidak valid, sehingga 21 butir valid digunakan untuk menjaring data berikutnya.

Penghitungan koefisien reliabilitas butir instrument menggunakan rumus koefisien Alpha Cronbach, melalui bantuan SPSS didapatkan data koefisien Cronbach Alpha Perilaku Penolakan Produk tidak Ramah Lingkungan sebesar 0,941.

Selanjunya dilakukan uji persyaratan analisis dan hasil analisis perhitungan menunjukkan bahwa sampel berdistribusi normal dan sampel menunjukkan populasi yang homogen, maka selanjutnya dapat dilakukan uji hipotesis penelitian. Pengujian hipotesis penelitian dilakukan dengan menggunakan Uji Koefisien Korelasi Ganda melalui bantuan SPSS versi 22.

\section{HASIL DAN PEMBAHASAN}

Analisis korelasi ganda dilakukan untuk mengetahui hubungan antara dua atau lebih variable independent $\left(\mathrm{X}_{1}, \mathrm{X}_{2}, \mathrm{X}_{3}, \ldots \mathrm{X}_{\mathrm{n}}\right)$ terhadap variable dependent secara bersamaan atau simultan. Berdasarkan tabel 4.11, dapat diketahui bahwa nilai signifikansi dari output diketahui antara Terpaan Berita Lingkungan (X1) dengan Rasa Ingin Tahu atas Isu Lingkungan (X2) memiliki nilai signifikansi $24,42>3,16$, artinya terdapat korelasi ganda yang signifikan.

Tabel 1 Uji Koefisien Korelasi Ganda

\begin{tabular}{|c|c|c|c|c|c|c|}
\hline $\begin{array}{c}\text { Sumber } \\
\text { Varians }\end{array}$ & $\mathbf{d k}$ & $\begin{array}{c}\text { Jumlah } \\
\text { Kuadrat (JK) }\end{array}$ & $\begin{array}{c}\text { Rata-rata Jumlah } \\
\text { Kuadrat (RJK) }\end{array}$ & F $_{\text {hitung }}$ & \multicolumn{2}{|c|}{ F $_{\text {tabel }}$} \\
\cline { 5 - 7 } & & $\mathbf{0 , 0 5}$ & $\mathbf{0 , 0 1}$ \\
Regresi & 2 & 3481,05 & 1740,52 & 24,42 & 3,16 & 5,00 \\
Residu & 57 & 4061,95 & 71,26 & & & \\
\hline
\end{tabular}

Dari tabel diatas dapat dilihat bahwa $F_{\text {hitung }}>F_{\text {tabel }}, F_{\text {hitung }}=24,42$ sedangkan $F_{\text {hitung }}$ $=3,16$, dengan hasil ini menjelaskan bahwa terdapat korelasi ganda yang signifikan antara terpaan berita lingkungan dan rasa ingin tahu atas isu lingkungan dengan perilaku penolakan produk tidak ramah lingkungan.

Selain itu peneliti juga melakukan Uji Koefisien Determinasi. Uji ini dilakukan 
untuk mengetahui besarnya persentase kontribusi antara variable,

(1) Koefisien Determinasi Terpaan Berita Lingkungan $\left(\mathrm{X}_{1}\right)$ terhadap Perilaku Penolakan Produk
Tidak Ramah Lingkungan (Y)

Hasil Analisis koefisien determinasi variable Terpaan Berita Lingkungan terhadap Perilaku Penolakan Produk tidak Ramah Lingkungan dapat dilihat dari tabel berikut:

Tabel 2 Uji Koefisien Determinasi

\begin{tabular}{|l|r|r|r|r|}
\hline Model & \multicolumn{1}{|c|}{$\mathrm{R}$} & R Square & \multicolumn{1}{c|}{$\begin{array}{c}\text { Adjusted R } \\
\text { Square }\end{array}$} & $\begin{array}{r}\text { Std. Error of } \\
\text { the Estimate }\end{array}$ \\
\hline 1 &, $611^{\mathrm{a}}$ &, 373 &, 362 & 9,032 \\
\hline
\end{tabular}

a. Predictors: (Constant), X1

Dari tabel diatas dapat diketahui bahwa nilai $\mathrm{R}$ sebesar 0,37. Sehingga kemampuan variable Terpaan Berita Lingkungan untuk menjelaskanPerilaku Penolakan Produk Tidak Ramah Lingkungan, secara parsial yaitu $37,3 \%$, sedangkan sisanya dipengaruhi oleh variable lain.

Koefisien Determinasi variable Rasa Ingin Tahu atas Isu Lingkungan terhadap
Perilaku Penolakan Produk tidak Ramah Lingkungan

Hasil Analisis koefisien determinasi variable Rasa Ingin Tahu atas Isu Lingkungan terhadap Perilaku Penolakan Produk tidak Ramah Lingkungan dapat dilihat dari tabel berikut:

Tabel 3 Uji Koefisien Determinasi

\begin{tabular}{|l|r|r|r|r|}
\hline Model & \multicolumn{1}{|c|}{$\mathrm{R}$} & R Square & \multicolumn{1}{c|}{$\begin{array}{c}\text { Adjusted R } \\
\text { Square }\end{array}$} & $\begin{array}{r}\text { Std. Error of } \\
\text { the Estimate }\end{array}$ \\
\hline 1 &, $562^{\mathrm{a}}$ &, 316 &, 304 & 9,433 \\
\hline
\end{tabular}

a. Predictors: (Constant), X2

Hitung uji koefisien determinasi dapat diketahui nilai $\mathrm{R}$ sebesar 0.316 . Sehingga kemampuan variable Rasa Ingin Tahu atas Isu Lingkungan untuk menjelaskan Perilaku Penolakan Produk tidak Ramah Lingkungan, secara parsial yaitu 31,6\%, sedangkan sisanya dipengaruhi oleh variable lain.

Berdasarkan hasil perhitungan yang telah dijelaskan diatas dapat diketahui bahwa terdapat hubungan yang positif antara Terpaan Berita Lingkungan dengan Perilaku 
Penolakan Produk Tidak Ramah Lingkungan dan Rasa Ingin Tahu atas Isu Lingkungan dengan Perilaku Penolakan Produk tidak Ramah Lingkungan.

Berdasarkan analisis regresi linier yang dilakukan terhadap pasangan data penelitian antara Terpaan Berita Lingkungan terhadap Perilaku Penolakan Produk tidak Ramah Lingkungan menghasilkan arah regresi sebesar 0,532. Sedangkan analisis regresi linier pasangan data penelitian antara Rasa Ingin Tahu atas Isu Lingkungan terhadap Produk tidak Ramah Lingkungan menghasilkan arah regresi sebesar 0,582.

Hasil uji koefisien regresi diatas yang digunakan untuk mengetahui pengaruh variable independent terhadap variable dependent apakah terdapat pengaruh yang signifikan atau tidak. Kriteria pengujian yaitu jika $\mathrm{F}_{\text {hitung }}<\mathrm{F}_{\text {tabel }}$ maka $\mathrm{H}_{0}$ diterima regresi tidak berarti, jika $\mathrm{F}_{\text {hitung }}>\mathrm{F}_{\text {tabel }}$ maka $\mathrm{H}_{0}$ ditolak dan regresi berarti. Didapati data bahwasannya, untuk X1 terhadap Y didapati hasil berdasarkan hasil perhitungan $\mathrm{F}_{\text {hitung }}=$ 26,77 dan $F_{\text {tabel }}=4,01$ sehingga $F_{\text {hitung }}>F_{\text {tabel }}$ maka dapat disimpulkan bahwa model persamaan regeresi adalah signifikan. Sedangkan untuk X2 terhadap Y didapati hasil berdasarkan hasil perhitungan $\mathrm{F}_{\text {hitung }}=$ 26,77 dan $F_{\text {tabel }}=4,01$ sehingga $F_{\text {hitung }}>F_{\text {tabel }}$ maka dapat disimpulkan bahwa model persamaan regresi adalah signifikan.

Untuk uji koefisien determinasi dapat diketahui nilai $\mathrm{R}$ sebesar 0.373. Sehingga kemampuan variable Terpaan Berita Lingkungan untuk menjelaskan Perilaku Penolakan Produk Tidak Ramah Lingkungan, secara parsial yaitu 37,3\%, sedangkan sisanya dipengaruhi oleh variable lain. Sedangkan hitung uji koefisien determinasi dapat diketahui nilai $\mathrm{R}$ sebesar 0.316. Sehingga kemampuan variable Rasa Ingin Tahu atas Isu Lingkungan untuk menjelaskan Perilaku Penolakan Produk tidak Ramah Lingkungan, secara parsial yaitu $31,6 \%$, sedangkan sisanya dipengaruhi oleh variable lain.

\section{KESIMPULAN}

Berdasarkan hasil penelitian yang telah dijelaskan, adapun kesimpulan yang diperoleh dari penelitian ini.

Terdapat hubungan yang positif antara Terpaan Berita Lingkungan denganPerilaku Penolakan Produk Tidak Ramah Lingkungan. Maka jika pemberitaan yang berkaitan dengan lingkungan positif maka diprediksi dapat meningkatkan penolakan perilaku masyarakat terhadap produk tidak ramah lingkungan dan untuk meningkatkan frekuensi ataupun kualitas pemberitaan lingkungan untuk meningkatkan ranah kognitif masyarakat sehingga berperilaku untuk menolak produk tidak ramah lingkungan.

Terdapat hubungan yang positif antara Rasa Ingin Tahu atas Isu Lingkungan dengan Perilaku penolakan produk tidak ramah 
lingkungan. masyarakat terhadap isu lingkungan tingga maka perilaku penolakan produk tidak ramah lingkungan akan semakin meningkat SLẸpisehingga rasa ingin tahu masyarakat terhadap isu-isu lingkungan perlu ditingkatkan untuk mendukung perilaku penolakan produk tidak ramah lingkungan.

Terdapat hubungan yang positif antara terpaan berita lingkungan dan rasa ingin tahu atas isu lingkungan dengan perilaku penolakan produk tidak ramah lingkungan.

Disimpulkan bahwa untuk meningkatkan Perilaku Penolakan Produk Tidak Ramah Lingkungan maka variable Terpaan Berita Lingkungan dan Rasa Ingin Tahu atas Isu Lingkungan perlu dipertimbangkan.

\section{DAFTAR PUSTAKA}

Abrar, A. N. (1993). Mengenal Jurnalisme Lingkungan. Yogyakarta: Gajah Mada University Press.

Anthony C. Klotz, M. R. (2013). A historical perspective of counterproductive work behavior targeting the organization. Journal of Management History , 19 (1), 114-132.

Ashri Noorida Permana, P. M. (2016). Proses Pendalaman Informasi Berbasis Informasi Awal Line BEM Fikom Unpad. Jurnal Kajian Informasi \& Perpustakaan, Vol 4 (No 1), 12.

Atmakusumah. (1996). Mengangkat Masalah Lingkungan ke Media Massa. Jakarta, DKI jakarta, Indonesia:
Yayasan Obor Indonesia dan Lembaga Pers Dr. Sutomo.

Ayuningtias, P. (2013). Hubungan Terpaan Media Mengenai Penculikan Anak di Televisi dengan Tingkat Kecemasan Orang Tua di RT 23 Kelurahan Sidomulyo Samarinda. eJournal Ilmu Komunikasi , I (2), 14-27.

Bernd Marcus, O. A. (2016). Structure of Counterproductive Work Behavior: A Review, a Structural Meta-Analysis, and a Primary Study. Journal of Management , 42 (1), 203-233.

Dea Rizki Kapriani, D. P. (2014). Efektivitas Media Sosial Untuk Gerakan Pelestarian Lingkungan. Jurnal Sosiologi Pedesaan IPB , II (3), 170.

Dewi, P. A. (2011). Praktik Jurnalisme Lingkungan oleh Harian Jawa Pos. Jurnal Ilmu Sosial dan Ilmu Politik, 15 (2), 205

Doubilet, D. (2016, October 13). National Geographic. Retrieved December 20, 2017, from National Geographic.com: www.nationalgeographic.com

Dwinanda, R. (2018, January Saturday). Sejumlah Perusahaan Terindikasi buang Limbah ke Citarum. Retrieved January saturday, 2018, from Republika.co.id:

http://republika.co.id/berita/nasional/d aerah/18/01/20/p2u2a2414-sejumlahperusahaan-terindikasi-buang-limbahke-citarum

Erlinda Muslim, D. R. (2014). Analisis Pengaruh Eco-Label terhadap Kesadaran Konsumen untuk membeli Green Product. Jurnal Manajemen Teknologi , 13 (1), 66.

Elvirnarno Ardianto, L. K. (2004). Komunikasi Massa: Suatu Pengantar. Bandung, Jawa Barat, Indonesia: Sambiosa Rekatama Media. 
F, R. (1989). Perbandingan Sistem Pers. Jakarta, DKI Jakarta, Indonesia: Gramedia.

Febrya, I. W. (2016). Penggunaan Green Cosmetic dalam Mewujudkan Perilaku Kesadaran Lingkungan. Jurnal Ilmu Lingkungan , 199-203.

Fiske, J. (2014). Pengantar Ilmu Komunikasi - Jakarta, DKI Jakarta, Indonesia: PT Raja Grafindo Persada .

Fitriyani. (2017, Desember 3). Megapolitan. Retrieved September 3, 2018, from Okezone News: news.okezone.com

Irna Hanifah Ameliah, M. M. (2016). Pengaruh Keingintahuan dan Rasa Percaya Diri Siswa Terhadap Hasil Belajar Matematika Kelas VII MTs Negeri I Kota Cirebon. EduMa, V(1), 9-21.

Jamilah Ahmad, H. L. (2016). Media and The Environment In Malaysia: An Analysis on News Coverage of Landslide in Kuala Lumpur. Malaysian Journal of Communication , 32 (2), 525-544.

James Purnama, N. (2014). Pengaruh Produk Ramah Lingkungan, Atribut Merek Hijau, Iklan Peduli Lingkungan dan Persepsi Harga Premium Terhadap Keputusan Pembelian Produk AMDK. Jurnal Fakultas Ekonomi , 1-9.

Jason A. Colquitt, J. A. (2013). Organizational Behavior Improving Performance and Commitment in The Workplace. New York: McGraw-Hill Irwin.

Jazeera, A. (2018, Januari 3). Suara Pembaruan. Retrieved Februari 3, 2018, from Akibat Bencana Iklim AS merugi US\$ 306 Miliar: http://sp.beritasatu.com/internasional/a kibat-bencana-iklim-2017-as-merugius-306-miliar/122201
Kurniawan, E. (2006). Studi Analisis Isi Pemberitaan Media Massa Tentang Lingkungan Hidup dan Implikasinya Terhadap Pengelolaan Lingkungan di Kabupaten Bangka.

Lu, T. K. (2014). Assesing The Variable That Influence The Intention Of Green. $E$ Journal Of Social Science Research, II, 1-14.

Mardhiyani, D. (2017). Upaya Meningkatkan Rasa Ingin Tahu Mahasiswa Melalui Penerapan Pembelajaran Berbasis Proyek pada Mata Kuliah Evaluasi Proses dan Hasil Pembelajaran Matematika. Jurnal Ilmiah Pendidikan Matematika , 5 (1), 1-8.

Mirawati. (2016). Hubungan Antara Pesan Kampanye 9 Aksi Ramah Lingkungan Dengan Sikap Follower Aktif Terhadap Gaya Hidup Ramah Lingkungan. Jurnal Manajemen Komunikasi , 1 (1), 125-144.

Mondry. (2008). Pemahaman Teori dan Praktik Jurnalistik. Bogor, Jawa Barat, Indonesia: Ghalia Indonesia.

Morissan, A. C. (2010). Teori Komunikasi Massa. Bogor, Jawa Barat, Indonesia: Ghalia Indonesia.

Morissan. (2013). Teori Komunikasi Individu Hingga Massa. Jakarta, DKI Jakarta, Indonesia: Kencana Prenada Media Group.

Mydha Tri Puspitasari, S. S. (2015). Upaya meningkatkan Karakter Rasa Ingin Tahu dan Hasil Belajar Akuntansi melalui Pembelajaran Kontekstual dengan Metode Snowball Throwing pada siswa SMK Muhammadiyah Gemolong. Tata Arta , I (1), 31-39.

Nik Fanidautty Nik Ab Majid, N. H. (2014). Assessing The Variables That Influence The Intention of Green Purchase (Vol. 
II). Pahang, Malaysia: Icssr E-Journal of Social Science Research.

Nurkamilah, M. (2017). Upaya Meningkatkan Keingintahuan Matematis Siswa Menggunakan Guided Discovery Learning Setting Kolaboratif. THEOREMS (The Original Research of Mathematics) , 1 (2), 51-63.

Rachmadi, F. (1989). Perbandingan Sistem Pers. Jakarta, DKI Jakarta, Indonesia: Gramedia.

Ramadhan, B. (2016). Walhi Terima 25 Pengaduan Kasus Lingkungan di Jabar selama 2016. Jakarta: Republika Online.

Suwardi, H. (1993). Peran Pers dalam Politik di Indonesia . Jakarta, DKI
Jakarta, Indonesia: Pustaka Sinar Harapan.

Widianto, D. (2017, November 1). Bupati Prihatin Kerusakan Gunung Beran. Retrieved Februari 3, 2018, from krjogja.com:

http://krjogja.com/web/news/read/493 05/Bupati_Prihatin_Kerusakan_Gunun g_Beran

Yuswantoro. (2017, Agustus Tuesday). Limbah Popok Bayi Picu Ikan Sungai Brantas Punah dan Jadi Banci. Retrieved Januari Thursday, 2018, from Sindonews.com: www.sindonews.com 